\title{
MEDŽELLA - NOVA PARADIGMA PRIMJENE KODIFIKOVANOG, ŠERIJATSKOG, MATERIJALNOG PRAVA U SUDSTVU
}

\section{Sažetak}

Materijalno pravo je ono koje sud primjenjuje kad odlućuje o meritumu stvari unutar postupka, a formalno se odnosi na pravila postupka, tako je materijalni, Kazneni zakon, a formalni, Zakon o kaznenom postupku. Medžella, o kojoj će biti riječ u ovom radu, sadrži vid kodifikovanog, šerijatskog, materijalnog prava.

Historijska analiza epoha razvoja islamske pravne misli upućuje na to da je islamsko pravo-fikh u svome razvoju i sistematizaciji prošlo više različitih faza ili epoha razvoja ${ }^{2}$ od kojih je podjela, koju je napravio Mustafa Ahmed EzZerka, spominjući sedam različitih faza, prihvatljiva za objašnjenje ovog fenomena $i$ savremenu kodifikaciju islamskog prava. Sedmu fazu koja obuhvata razvoj fikha, kako kaže autor, od pojave „Medželle“ do danas, karakterišu tri bitne stvari od kojih je prva: Uzimanje i proglašavanje "Medželletul-ahkjamul-a'dlijje“ kao općeg gradanskog zakona uzetog iz hanefijskog fikha.

${ }^{1}$ Islamski pedagoški fakultet u Bihaću

${ }^{2}$ Neki islamski pravnici, kao što je šejh Muhammed El-Hudaribeg, smatraju da je šest faza u razvoju islamskog fikha:

1. Vrijeme Objave, života i rada Allahovog Poslanika, a.s.,

2. Vrijeme velikih ashaba koje završava sa Pravednim halifama,

3. Vrijeme mlađih ashaba koje prestaje završetkom I stoljeća Hidžre,

4. Faza u kojoj fikh postaje zasebna nauka i u kojoj se pojavljuju pravni znalci i njihovi učenici i sljedbenici a koja završava sa III stoljećem Hidžre,

5. Faza u kojoj nastaju pravne rasprave, disputacije i veliki pravni zbornici a završava sa padom Abbasijske države i Bagdada te prodorom i osvajanjem Tatara i

6. Faza čistog slijeđenja, imitacije i oponašanja koje nastupa iza prethodne faze i traje do danas. 
U poglavlju Gradansko pravo, Opšta enciklopedija Larousse, spominje se da bivša zemlja Jugoslavija, u razdoblju izmedu dva svjetska rata, Prvog $i$ Drugog, nije imala jedinstvenu gradansko-pravnu teritoriju, nego se sastojala iz šest pravnih područja od kojih je posebno gradansko-pravno područje činila Bosna i Hercegovina gdje „su se primenjivali otomanski svetovni zakoni (Medžele), muslimansko versko pravo (Šerijat), konfesionalna hrišćanska prava, običajno pravo i OAGZ kao dopunsko pravo"s. Za poznavaoce Šerijata i islamskog fikha ova kvalifikacija o Šerijatu i Medželli je netačna, ali odražava stav konvencionalnih pravnika, njihovo nepoznavanje $i$ nerazumijevanje biti šerijatskog prava. Niti je Medžella svjetovni zakon, dakle laički, niti Šrijat samo muslimansko vjersko pravo. To se vidi čak $i$ iz originalnog naziva Medželle koji stoji u naslovu prijevoda na bosanski jezik Medželle i abkjami šerije, i upúcuje na općepoznatu kodifikaciju šerijatskog prava ili hanefijskog mezheba u tzv. fikhu mua'melata...

Glavna karakteristika fikhskih pravnih zbornika leži u činjenici velike disperzije i nejedinstva pravnih stavova i mišljenja. Mišljenja su davali pravni eksperti kroz pravno rezonovanje koje je bilo, bez obzira na sve, legitimno i po uvjetima metodologije islamske jurisprudencije. Radilo se o tzv. fikhu tefsiri i tefsili (komentar i naučna objašnjenja) deriviranom naučnom metodologijom iz temeljnih tekstova i izvora Šrijata kao najveća $i$ najobimnija pravna baština koju je svijet upoznao. Predstavljena je u pravnim školama (mezhebima) poznatih učenjaka sa razlazom metodološke i pravno-praktične prirode koja je pričinjavala teškoću u primjeni. Bio je to dovoljan razlog da se pokusa novi vid kodifikacije, koja će se ostvariti izradom Medželle, čija je najveća odlika ta što se njome napravila razlika između naučnog - stručnog prava koje se objašnjava, predaje i tumači, i prava koje je materijalni sudski izvor u vidu samo jednog odabranog stava pretvorenog u član/paragraf. To je epohalni, revolucionarni preokret u primjeni islamskog fikha, te se s pravom može smatrati novom paradigmom primjene kodifikovanog, serijatskog, materijalnog prava $u$ sudstvu $i$ velikim korakom $k a$ uniformnom, jedinstvenom tumačenju i primjeni prava i jedinstvenosti sudske prakse.

${ }^{3}$ Građansko pravo, Opšta enciklopedija Larousse, (Vuk Karadžić, Beograd, 1971), I, 249. 
Pravna osnova za sve ovo potvrdena je i objašnjena u stavu 1801. Medželle u kojem se kaže da ako sultan izda naredbulukaz da se postupi po nekom stavu, iz razloga š to je to u korist ljudi i š jo je primjerenije za savremeno doba, onda nije $u$ ingerenciji sudije da sudi $i$ radi po nekom drugom mišljenju i stavu. Ako bi to učinio, njegova odluka nije izvršna i sprovodiva. Potvrda za to je $i$ stav 16. Medželle koji glasi: Idžtihad, stav nekog pravnog eksperta ne dokida se idžtihadom, pravnim rezonom istog takvog drugog eksperta.

Ključne riječi: Medželle i ahkjami šerije (Otomanski gragjanski zakon) Medželletul-ahkjam el-a'dlijje (Kodeks pravnih propisa), fikh, kodifikacija fikhalprava, idžtihad, mudžtehid mutlak, pravno rezonovanje, tradicionalni izvori prava, uniformno jedinstveno tumačenje i primjeni prava, unificiranost sudske prakse...

\section{Razlozi koji su doveli do kodifikacije fikha}

Islamsko zakonodavstvo, iako podliježe ljudskom tumačenju, ima božansko porijeklo u tradicionalnim izvorima i ne pravi razliku između ljudi niti preferira pravne adresate u pravednosti i jednakosti; muslimana nad nemuslimanom, plemića nad običnim čovjekom. To zakonodavstvo nije obespravilo ženu, nego joj je epohalno, revolucionarno popravilo status... Njegova primjena se raširila po svijetu, bez obzira protivnike i neprijatelje. Činjenica je da su mnogobrojna zakonodavstva proizišla iz šerijatskog. Uzvišeni konstatira u Kur'anu:

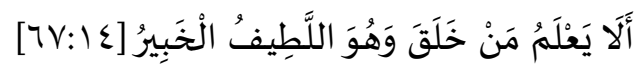

A kako i ne bi znao Onaj koji stvara, Onaj koji sve potanko zna, koji je o svemu obaviješten.

Muhammed El-Hasen El-Bega spominje u svom radu Et-Taknin kema jebdu fi medželletil-ahkjamil-adlijje da je Napoleon Bonaparte, kao što su zabilježili francuski historičari, napisao čuveni zakon uzet iz islamskog fikha, izostavljajući ono što se odnosilo na vjerska pitanja. Francuski historičari su svoj rad temeljili na Šafijinoj knjizi El-Umm koja je i jeste 
temelj šafijskog Novog mezheba u Egiptu, regulirajući oblast civilnog ili građanskog prava na način koji Zapad prije toga nije poznavao ${ }^{4}$.

Mnogi ne znaju da je žena i u našim krajevima bila obespravljena i hiljadu godina nakon što ju je islam oslobodio i dao joj pravo nasljedstva božanskom normom Kur'ana. Tek dolaskom islama u naše krajeve, šerijatsko zakonodavstvo izjednačuje obespravljenu ženu sa muškarcem u pravu nasljeđivanja, za koje je ona bila prikraćena običajnim pravom, posebno u domenu nasljeđivanja nekretnina.

Dr. Vojislav Spaić je, 1967. godine, objavio vrijednu naučnu studiju pod naslovom Nasljednopravni običaji u BiH nakon Austro-Ugarske okupacije, $\mathrm{u}$ zbirci Radovi Akademije nauka i umjetnosti Bosne i Hercegovine $\mathrm{u}^{5}$ kojoj je objavio integralni tekst Projekta nasljednog zakona, urađen prije Drugog svjetskog rata, ali nikad nije službeno ozakonjen.

On navodi u svojoj studiji o nasljeđivanju žena: “... pa se, s potpunim pravom, može reći da su žene bile isključene iz nasljeđivanja nekretnina. Osim toga, ne smijemo zaboraviti da su ovi pravni običaji koji dozvoljavaju ženama nasljedstvo vlastite zemlje nastali pod utjecajem turskog zakonodavstva.'

Islamsko pravo je imalo svoje faze, primjene i uticaj kroz različite vremenske epohe u svom dijalektičkom evolutivnom razvoju i kodifikaciji.

Općenito, ideja kodifikacije je bila poznata od vremena osnivanja islamske države. Prvo je sabran i kodifikovan Kur'an na način da se zapisao i napravio primjerak kompletne verzije u zbirci Mushafa. Zbirka je recenzirana od strane komisije pismenih ashaba, metodom komparacije i uz hafize koji su kompletan kur'anski tekst napamet memorisali.

\footnotetext{
${ }^{4}$ http://www.taddart.org/?p=12736

5 Vojislav Spaić, Nasljednopravni običaji u BiH nakon Austro-Ugarske okupacije, Akademija nauka i umjetnosti BiH, knjiga XXXII., Odjeljenje društvenih nauka, knjiga 11., Sarajevo, 1967.

${ }^{6}$ Ibid., 64. Vidi, također, o utjecaju turskog zakonodavstva, str. 61.
} 
Naposljetku to je umnoženo i poslano u centre islamske države. Isto je učinjeno i sa sunnetom koji je sabran, zapisan i sačuvan poslije Kur'ana.

U pravnom smislu, kodifikacija je sabiranje propisa i zakona pojedinih pravnih problema u jednom poglavlju, metodologijom članova/paragrafa. Kod rješavanja jednog pravnog problema zadovolji se samo jednim odabranim propisom, izdvojenim iz različitih mišljenja/rješenja, koja su izrekli pravnici, da bi olakšali sudijama poznavanje odabranih propisa.

Još vrlo rano u islamskoj državi, Ebu Dža'fer El-Mensur, tražio je od imama Malika (93-179. g. po h.), utemeljitelja malikijskog mezheba, da prisili ljude na slijeđenje stavova iz njegove knjige El-Muvetta'. Imam Malik, r.h., je odbio, rekavši: Svaki narod ima svoje stare autoritete i imame, pa ako ih vladar pravovjernih podrži u tome, neka to i učini.

Sudije i ljudi se referiraju na knjige i pravne zbornike u svojim sporovima i problemima, sa oslanjanjem na zbornike decizija. Ovo je trajalo vjekovima, dok osmanlijski sultan Sulejman El-Kanuni u 10. hidžretskom stoljeću nije naredio šejhu Ahmedu El-Halebiju da sakupi sažetke hanefijskih pravnih tekstova i zbornika. On je to i učinio - sabrao i napisao djelo Multekal-ebhur.

Zatim je u XI stoljeću došao mogulski sultan Muhammed El-Alemkir u hidžre i naredio da se zapišu Zahirur-rivajeti iz hanefijskog mezheba, fetve/decizije uleme i tzv. mes'ele Nevadira. Ulema se složila, te je nastalo fikhsko djelo nazvano Fetava Hindije ili Alemkirije.

Općepoznato je da su postojala mnogobrojna pravna rješenja islamskih pravnika. Tako je izdan Sultanski ukaz u osmanskoj državi, sačinjena zbirka/ zbornik šerijatskih propisa (zakonskih članova/paragrafa u hanefijskoj pravnoj školi) i osnovana komisija od sedam članova pod vođstvom Ahmed Dževdet paše, nadglednika Divana.

\section{Pravna osnova uzimanja samo jednog stava kao princip Medželle}

Kako bi se riješilo pravnog razlaza i sporenja, koje uveliko otežava sudsku primjenu u kojoj se mora praviti izbor, došlo se do principijelnog stava da kada islamski vladar odabere i naredi neku dozvoljenost, obaveza je da se 
pravni adresati tome pokore. Ako nešto zabrani obaveza je da se i to poštuje.

Na to upućuju tradicionalni izvorni tekstovi Šerijata, a Kur'an proklamuje:

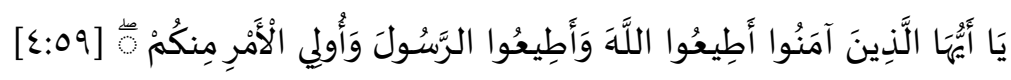

zahtijeva

zahtijevaju

U hadisu se kaže:

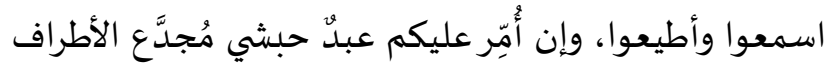

Slušajte i pokoravajte se pa makar vam bio nadređen Abesinski rob otkinutih ušiju.

Unificiranost primjene propisa i jedinstvo mišljenja se postiže primjenom pokornosti jednog rješenja.

Kada se muslimani raziđu zbog različitih dozvoljenih mišljenja i predstavnici vlasti ograniče samo jedno od njih, te narede da se primjenjuje kako bi se spriječilo razilaženje; onaj ko se razilazi ima obavezu uvažiti taj stav, prema navodima El-Karafi. Razlog tome je stabilnost propisa, izbjegavanje svađe $\mathrm{i}$ prepirke $\mathrm{i}$ uništenje anarhija, nereda i inata. Zakonodavac ima legitimitet da obaveže, a njegova naredba (ako je dozvoljenom) ista je po pravnoj snazi kao i tekst koji dođe od strane Uzvišenog Zakonodavca. Tako muftija/sudija ne bi smio da donosi deciziju suprotnu stavu vladara/zakonodavca koji se primjenjuje, jer njegova odluka i legitimni odabir u tom domenu poništava razdor $\mathrm{i}$ sporenje, u stvarima koje su podložne idžtihadu/pravnom rezonovanju eksperta i razilaženju.

To je ono što je došlo kao princip u Medželli u vidu člana 1801. u kojem se kaže:

...Ako bi izašla carska zapovijed da se postupa prema nazoru (mnijenju) jednog učenjaka pravničkog, jer je to njegovo mnijenje u toj stvari za svijet, za potrebe vremena, koristnije (probitačnije) ne smije sudac suditi u toj stvari po 
nazoru drugog nekog pravničkog učenjaka, koje je mišljenje protivno prvome, ako bi to učinio, osuda mu neće biti ovršljiva (valjana) ${ }^{7}$.

Osmanska država je prihvatila hanefijski mezheb kao službeni od vremena Selima I, tako da su šejhul-islam, muftije i sudije postupali, sudili i donosili decizije u skladu sa ovim mezhebom. To je bio korak na putu kodifikacije islamskog fikha, potvrđen i objašnjen stavom 1801. Medželle: ako sultan izda naredbu/ukaz o postupku, po stavu nekog pravnog eksperta, iz razloga što je to u korist ljudi i što je primjerenije za vrijeme, onda sudija ne može da sudi i radi po nekom drugom mišljenju i stavu. Ukoliko bi to učinio, njegova odluka ne bi bila sprovodiva i izvršna. Isto tako i stav 16. u Medželli glasi: Idžtihad, stav nekog pravnog eksperta se ne dokida idžtihadom, pravnim rezonom istog takvog drugog eksperta. (الاجتهاد لا ينقض (بمثله

Vremenom je Osmanska država odustala od prid ržavanja samo hanefijskog mezheba, prakticirajući druge mezhebe i njihova rješenja, kao što je bio slučaj sa porodičnim pravom.

U mnogobrojnim reformama osnovano je jedno tijelo najpoznatijih pravnih eksperata toga doba koje je imalo zadatak da kodifikuje islamsko pravo/fikh. Oni su 1286. h., podnijeli izvještaj. U tom izvještaju uočava se da nema sinhronizovanog pravnog sistema šerijatskih i konvencionalnih sudova. Isto tako fikhska baština je more kojemu nema kraja da bi se riješio neki pravni problem. Hanefijski mezheb, u kojem su se mnogobrojni pravni eksperti različiti po autoritetu, u puno praktičnih primjera razišli, nije bio dovoljno iskristalizirao mnogobrojne propise. Takav slučaj je sa šafijskim mezhebom. Što će reći da je, uz promjenu urfa i adeta, odvajanje ispravnog mišljenja u moru pravne baštine iz različitih vremena i njegova primjena na realnim/aktualnim pravnim događajima izuzetno težak zadak.

Za razlikovanje razlaza zbog vremena ili zbog dokaza potreban je izuzetan ekspert. Zbog toga su knjige pisane od strane vrhunske uleme decizija. Jedna takva je i zbornik decizija Fetava Et-Tatarhanije i El-Alemkirije

${ }^{7}$ Medželle i abkjami šerije: 615. 
poznate kao El-Fetava El- Hindije. Ni to nije bilo dovoljno za sva pojedinačna, praktična, pravna pitanja i postojeći pravni razlaz.

Knjige fetvi su sadržavale ono što je praktično rješavano od strane uleme po nekom pravnom problemu. Ibn Nudžejm je sakupio mnogobrojna pravna pravila i opće situacije pod kojima su podvedena mnogobrojna praktičnopravna fikhska rješenja pojedinačnih pitanja.

\section{Razlozi za izradu Medželle}

Vrlo rijetko ili gotovo da ne postoje učenjaci, pravni eksperti iz svih oblasti fikha, (tzv. mudžtehid mutlak) tako da je na velikim mukama i problemima obični sudija ili muftija kada treba donijeti presudu ili dati pravni savjet. To se jasno vidi iz sljedećih činjenica:

Samo u hanefijskom mezhebu, a slično je i u ostalim pravnim školama, postoji više vrsta pravnih mezhepskih mišljenja po nekom pitanju, u zavisnosti od njihove pravne snage; postoji specifična mezhepska pravna terminologija; poseban način preferiranja mezhepskih stavova svrstanih u tri kategorije:

1. Mesailul-usul مسائل الأصهول (temeljne mes'ele-pitanja) koja se zovu i zahirur-rivaje_ظاهر الرواية (očevidno, jasno ezoterično predanje).

2. Mesailun-nevadir مسائل النوادر (rariteti, rjetkosti, malobrojna pitanja) jesu mes'ele prenesene od mezhepskih učenjaka ali ne u zbirci Zahirur-rivaje ظاهر الرواية, nego u drugim Muhammedovim knjigama kao što su El-Kisanijat, El-Harunijat, El-Džurdžanijat, Er-Rikkijjat, El-Meharidž fil-hijel, Zijadetuz-zijadat koju prenosi Ibni Rustem.

3. El-vaki'at vel-fetava الواقعات و الفتاوى (pravni događaji i decizije). U ovu kategoriju spadaju pitanja koja su riješli pozni mezhepski pravni

\footnotetext{
${ }^{8}$ Vidi, H.M. Handžić, Kodificiranje šerijatskog prava kod raznih pravnih škola, predgovor u: Tumač šerijatskih propisa (H. Muradbegović), 260.
} 
eksperti kada su pitani o pojedinim pitanjima za koja nisu postojala mezhepska rješenja njihovih prethodnika i imama ${ }^{9}$.

Uz ovu disperziju i različitosti pravnih pitanja vrijede posebna i komplikovana pravila preferiranja, koja bi sudija trebao znati primijeniti u mezhebu, ako se ostane bez uniformnog rješenja u mezhebu ${ }^{10}$.

Tako npr.:

- Preferira se mišljenje imama Ebu Hanife, općenito, a posebno u oblasti pravne grane ibadata (obredoslovlje).

- Preferiranje mišljenja njegove dvojice učenika ili jednog od njih, dolazi samo u slučaju da je Imamov dokaz slabiji, u slučaju nužde ili potrebe ili u slučaju promjene mjesta i vremena zbog čega se, svakako, mogu promijeniti propisi.

- Uzima se fetva po mišljenju Ebu Jusufa u sudskim sporovima, kod svjedočenja, i u nasljednom pravu zbog njegovog posebnog iskustva $\mathrm{u}$ ovim oblastima.

- Mišljenje Muhammeda uzima se u pitanjima srodstva, a po mišljenju Zufera u posebnih 17. mes'ela.

- Ako ne postoje predaje rješenja neke mes'ele od Imama, onda se redoslijedno uzima rješenje Ebu Jusufa, potom Muhammeda, pa Zufera, i na kraju El-Hasen b. Zijada.

- Ako u nekoj mes'eli imamo rješenje na temelju kijasa i istihsana, onda se primjenjuje rješenje na temelju istihsana, općenito, osim u poznate 22. mes'ele gdje se preferira rješenje analogijom.

- Ako neka mes'ela nije spomenuta u kategoriji zahirur-rivaje onda se pribjegava nekom drugom slabijem rivajetu.

9 Opširnije vidi u: Uvod u šerijatsko pravo (fikh) $i$ njegovu metodologiju (usuli fikh), Muharem Štulanović, (Bihać, 2002), 44-47.

10 Ibid: $55-57$. 
- Ako se desi da dođu različiti rivajeti od Imama, onda se uzima po najjačem dokazu.

- Ako nema rivajeta njegovog rješenja, niti njegovih učenika, onda se uzima po konsenzusu poznih šejhova (mezhepski učenjaci nakon imama Ebu Hanife). Ako su se i oni razišli, onda se uzima po mišljenju većine.

- Međutim, ako nema ni mišljenja poznih šejhova, onda će sudija/muftija da upotrijebi sve svoje intelektualne sposobnosti da dođe do optimalnijeg pravnog rješenja, tražeći dokaz i bojeći se Uzvišenog, usklađujući svoje mišljenje sa općim načelima i intencijama Šrijata.

Kad sve ovo znamo i analiziramo s pravom se postavlja dilema: koji ekspert može imati uvid u sve ovo prilikom odabira nekog stava za sudsku presudu ili deciziju?

Dakle, ne može se lahko ni zamisliti koju teškoću predstavlja praktični odabir nekog rješenja, za sudiju ili muftiju, ako nema unutarmezhepskog jedinstva i uniformnog rješenja po određenom pitanju.

Prema tome, izlaz je bio da se saberu i napišu knjige fikhskih propisa koji će biti u vidu sročenih članova/paragrafa i na šta će se moći lahko referirati, a neće sadržavati poznati pravni razlaz i sporenje. Sadržavat će samo odabrane, najkorisnije stavove, koje bi svako mogao čitati, a od koristi je svima koji su vezani za pravnu nauku.

Osim ovih subjektivnih poteškoća, unutar samog islamskog društva, postojali su objektivni razlozi i faktori, te vanjski pritisci koji su doprinijeli jačanju ideje o potrebi kodifikacije građanskog prava. Među njima je projekt modernizacije i reformi (Tanzimat), započet 1839., i uspostava principa jednakosti svih podanika, te osnivanje građanskih sudova (mehakim-i nizamiye), nadležnih da presuđuju građanske stvari. Uz to evropski saveznici tražili su od Osmanske države da donese zakonik po uzoru na tadašnje evropske kodifikacije.

Unutar političkih elita vodila se borba kojim smjerom krenuti, da li recepcijom stranog građanskog zakonika (francuskog) ili kodifikacijom 
građanskog zakonika na temelju šerijatskog prava? Prevagu je odnijela struja na čelu s Ahmed Dževdet-pašom, koja se zalagala za kodifikaciju šeri'atskog prava. Ova odluka je predstavljala prekretnicu, jer se pokazalo da je i šerijatsko pravo, bez obzira na sve poteškoće, podesno za kodifikaciju i da samim time može odgovoriti savremenim izazovima društva, koje se naglo mijenjalo iz feudalizma srednjeg vijeka u kapitalizam modernog doba.

\section{Izrada Medželle}

Zbog svega izloženog, u Osmanskoj državi dolazi do izdavanja „Sultanskog dekreta" 1867. god. o osnivanju Vijeća pravnih eksperata, sedmočlanog odbora, kolegija koji će ustrojiti i odabrati šerijatsko-pravna rješenja hanefijskog mezheba iz grane građanskog prava (mu'amelat) onih pitanja koja su najviše i najčešće u upotrebi. Da bi se ovo postiglo uradila se Medžella. Prva knjiga Medželle podnesena je na usvajanje 11. 04. 1869., a posljednja 17.09. 1876. god.

Čim su napisani Uvodi Prva knjiga, materijal je dat na uvid i recenziranje. Date su primjedbe Islamskoj zajednici i nekim ličnostima, poznatim kao fikhski znalci i eksperti šerijatskog prava. $U$ isto vrijeme materijal je preveden na arapski jezik, a onda se pristupilo pisanju i šesnaest drugih poglavlja/knjiga.

Tako je nastao kodifikovani pravni zbornik „Medželletul-abkjam ela'dlijje" (Kodeks pravnih propisa), urađen u Osmanskoj državi od strane posebne zakonodavne komisije koju je vodio ministar pravde Ahmed Dževdet-paša u periodu od 1869-1876. god. ${ }^{11}$ Prevedena je i objavljena u Sarajevu 1906. god. (Asim Škaljić) pod nazivom Medželle i ahkjami šerije (Otomanski gragjanski zakon) ${ }^{12}$. Sadrži 99 temeljnih, načelnih, pravnih

\footnotetext{
11 Vidi, prof. dr. Mustafa Imamović, Historija države i prava Bosne $i$ Hercegovine, (Sarajevo, 1999), 237.

12 Vidi, Medžele $i$ abkjami šerije (Otomanski gragjanski zakon), (Sarajevo, Tisak i naklada Daniela A. Kajona 1906), reprint-preštampano izdanje koje je priredio i dopunio sa predgovorom i člankom „Šerijatsko pravo u Bosni i Hercegovini" i izvodi iz propisa, Mehmedalija Huremović u izdanju Bosanskog kulturnog centra, Sarajevo, maj, 1997.g.
} 
regula (od člana 2. do 100.), uzetih iz knjiga Ibn Nudžejma i Hadimija, sa dodatkom još nekih koje se ne nalaze u njima. Pod rednim brojem jedan je definicija i podjela fikha na pravne grane. Članovi ili paragrafi su od 100-1851, kako se kaže u uvodu: „Ostala pravna pitanja, kojih je rješenje u pravilima sadržano." Formalno nije bila proglašena za zakon, a objavljivana je sukcesivno $i$ uporedo u službenom osmanskom zborniku zakona Destur (Düstür), te na francuskom jeziku kao Osmanski gradanski kodeks (Code civil ottoman) i uživala je silu i autoritet zakona.

U „Medželli“ su, između ostalog, odabrana i neka slaba mezhepska mišljenja zbog vremenske koristi. Ne sadrži oblast ibadata (obredoslovlje), porodičnog prava i sankcija. Spomenula je i neke članove koji nisu utemeljeni kod hanefijskih pravnika, mada su uzeti iz mezheba kao slabija mišljenja. Predstavlja kodifikaciju imovinskog, obligacionog prava na koje se odnosi 13 knjiga i građanskog procesnog prava na koje se odnose 3 knjige. Dakle, Medžella je tretirala mnogobrojna pitanja i oblasti, civilni zakon, temelje formalnog, procesnog i tužbenog prava i mnoga pitanja trgovačkog prava.

Porodično i nasljedno pravo su izostavljeni. Svaka knjiga započinje sa objašnjenjem obavezne terminologije za slijeđenje i navodi najkorisniji stav iz hanefijskog mezheba, ne ograničavajući se na preferirani ili na zahirurrivaje/stav. Država ili vlast je na takav način čuvala autoritet sudije i kontrolisati sudstvo.

Prema svemu navedenom može se konstatovati:

1. Medžella je bila izvor šerijatskim i konvencionalnim sistemskim državnim sudovima za primjenu pravnopraktičnih propisa po fikhskim pravilima prema potrebama vremena, a to zbog naredbe vladara da se uzme po jednom obaveznom određenom propisu.

2. Rijetkost je postojanje eksperata u svim oblastima fikha i nepremostiva teškoća je u pronalasku sudija koji su sposobni da sude u šerijatskim sudovima, konsultujući se i referirajući na ogromnu pravnu baštinu koju bi sudija trebao da poznaje da bi mogao suditi. Ovo je uslovilo da se $\mathrm{u}$ području praktičnopravnih propisa fikha napiše djelo koje će sadržavati preferirane i odabrane stavove, na koje će se moći lahko 
referirati, a služit će onima koji se bave pravom, decizijama, suđenjem i administracijom.

3. Ova kodifikacija je nazvana „Medželletul-ahkjam el-a'dlijje”(Kodeks pravnih propisa), napisana je na turskom jeziku i uporedo prevedena na arapski jezik kao referentna osnova. Objavljena je i na francuskom jeziku kao Osmanski civilni kodeks. Napravljena je razlika između argumentovanog i vremenskog razlaza, što je iziskivalo oslonac na knjige decizija koje su napisane kao primjeri praktičnih rješenja na temelju pravnih pravila.

4. Temeljenje propisa, koje je moguće mijenjati zbog promjene vremena, na u'rfu i običaju, kao što je bio običaj kupovine kuće tako da se, po potonjim pravnicima, odredila obaveza gledanja svake kuće koja se kupuje, iako to prijašnja ulema nije obavezivala.

5. Pravljen je izbor iz stavova hanefijskog mezheba, a ponekad i iz drugih mezheba ako je to zahtijevala javna korist i situacija ljudi.

6. Medžella je recenzirana od najviših dužnosnika islamske zajednice kao i od najboljih i najelitnijih učenjaka, poznavaoca fikha.

1293. h. godine izdan je Sultanski Dekret kojim se proklamuje da je „Medžella“ obavezni pravni izvor u državnim sudovima. Ovim je sadržaj „Medželle“ postao općim građanskim zakonom, a sudije su bile obavezne na njenu primjenu.

\section{Recepcija (primjena) Medželle}

Medžella je primjenjivana na cijeloj teritoriji tadašnje Osmanske države. Nakon proglašenja republike u Turskoj je važila sve do 1926. kada je recipiran sekularni Švajcarski građanski zakonik. U Palestini, Transjordaniji, Siriji, Libanu i Iraku je važila sve do donošenja nacionalnih građanskih zakonika, nakon Drugog svjetskog rata. U Izraelu je važila sve do 1972. kao zemaljsko pravo naslijeđeno iz vremena britanskog mandata i osmanske uprave nad Palestinom. Važila je i na Kipru do šezdesetih godina prošlog stoljeća, u Albaniji do 1928. godine i na sudovima sultanata Džohor (Malezija), a važila je u Indiji i Pakistanu. Prevedena na 
farski jezik, primjenjivana je i dalje se primjenjuje u Afganistanu. U BIH je važila u vrijeme Austro - ugarske uprave kao zemaljsko pravo. Šerijatski sudovi u BIH primjenjivali su Medžellu sve do njihovog ukidanja 1946.

Nova legislativa Arapskih zemalja obuhvatila je 1953. Siriju, 1956. Tunis, 1958. Maroko, 1959. Irak, 1976. Jordan, 1978. Jemen, 1984. Kuvajt i Alžir i 1992. Sudan.

Medžella nije primjenjivana na Arapskom poluostrvu, Jemenu i Egiptu. Zemljama koje nisu bile pod Turskom upravom.

\section{Prednosti i odlike Medželle}

Medžellom se dobilo sljedeće:

1. Prelazak islamskog fikha iz mnogobrojnih tekstova, komentara, primjedbi, stavova i njihovih preferiranja u hanefijskom mezhebu $\mathrm{u}$ samo jedan stav na koji se može osloniti.

2. Stavljanje stava na koji se može osloniti u svakom pojedinačnom pitanju u poseban obavezujući zakonski član/paragraf.

3. Potpuni izostanak pravnog razilaženja i sporenja koji je štetan za praktičnu primjenu.

4. Ograničenje i određivanje zakonskog izvora sudijama prilikom suđenja u različitim oblastima.

5. To je jedan vid objedinjavanja i jedinstva muslimana u zakonu koji je povezan.

6. Ograničavanje suđenja u skladu sa hanefijskim mezhebom, isključujući razlaz, sporenje i anarhiju u suđenju prema različitim mezehbima i samostalnim sudijskim nahođenjima.

\section{Glavne primjedbe Medželli:}

1. Zadovoljavanje sa hanefijskim mezhebom bez drugih mezheba, iako su bili priznati u Osmanskoj državi i uživali pravni legalitet i legitimitet. Najkorisniji stav za Medžellu nije samo ekskluzivna vrijednost u hanefijkom mezhebu, što se pokazalo tačnim kod pitanja 
teorija zakonske ništavosti, uvjeta kod ugovora, te neuvažavanje koristi kao jednog vida imetka.

2. Puno je ponavljanja bez navođenja opće teorije o ugovorima i obavezama iako su sami propisi navedeni u podnaslovima i pojašnjeni. Ponavljani u svim knjigama umjesto da se jednom spomene samo opća teorija.

3. Stavke su ponekad predugačke i previše je bespotrebnih pojašnjavajućih termina, tako da ponekad podsjeća na ranije fikhske zbornike koji nisu kodifikovani na ovaj način.

4. Medžela ne sadrži propise porodičnog, testamentarnog ili nasljednog prava, vakufa, izgubljenih stvari i ne tretira neka druga pitanja čija rješenja postoje gotovo u svim pravnim zbornicima.

5. Obaveznost da se prihvati samo jedan stav, neminovno je vodilo $u$ zamrzavanje idžtihadskog napretka.

\section{Zaključak}

Najveća odlika „Medželle“ je pravljenje razlika između naučnog, stručnog prava koje se objašnjava, predaje i tumači i prava koje je materijalni sudski izvor, sa samo jednim odabranim mišljenjem pretvorenim u član/paragraf. Prema tome to je epohalni i revolucionarni preokret u primjeni islamskog fikha i s pravom se može tretirati novom paradigmom primjene kodifikovanog, šerijatskog, materijalnog prava u sudstvu.

Ujedno izradom Medželle učinjen je ogroman korak ka uniformnom, jedinstvenom tumačenju i primjeni prava i jedinstvenosti sudske prakse. Pitanje uniformnog tumačenja i primjene prava jedno je od najvažnijih pravnih pitanja uopće, jer iz ujednačenog tumačenja iste odredbe zakona, propisa ili drugog općeg akta, slijedi i jednaka primjena prava o kojoj u pravilu ovisi i jedinstvenost sudske prakse kao jednog od izvora prava ili precedenta. U slučajevima kada se na isto ili slično činjenično stanje treba primijeniti odgovarajuća pravna norma, njezino tumačenje i primjena trebaju biti ujednačeni u svim slučajevima. Rješavanje predmeta iste činjenične i pravne osnove na isti način čini jednu od osnova pravilnog 
funkcioniranja pravnog sistema uopće. Kada je u pitanju šerijatsko pravo Medžella je bila epohalan korak i u tom pravcu kao model ujednačavanja tumačenja i primjene prava koja je vodila do unifikacije i jedinstvenosti sudske prakse.

\section{Literatura:}

1. dr. Abdul-Kerim Zejdan, El-Vedžizu fi usulil-fiqh (Kompendijum metodologije islamske jurisprudenije), (Muessesetur-risale, 1987.),

2. dr. Abdul-Vehhab Ibrahim Ebu Sulejman, El-Fikrul-usulijj (Pojam metodologije islamske jurisprudencije), (Daruš-Šuruk, Džidda, 1984.),

3. Alaud-din Es-Semerkandi, Tuhfetul-fukahai (Raritet za islamske pravnike), (Idaretu ihjait-turasil-islami, bez godine izdanja),

4. A'li b. Ahmed b. Hazm El-Endelusi, El-Muhalla bil-asar (Zaslađeno vijestima), (Darul-kutubil-i'lmijje, Bejrut, Libanon, 1988.),

5. Burhanud-din, Ebul-Hasen El-Marginani, El-Hidaje šerh bidajetilmubteda (Uputa, komentar početog početka),

6. Dželalud-din Es-Sujuti El-Ešbahu ven-nezairu fi kava'id ve furu'i fikhiššafi ỉjje (Sličnosti i uporednosti u metodologiji i pravu šafijske pravne škole), (Darul-kutubil-ilmijje, Bejrut, 1979.),

7. Ebu Hamid Muhammed El-Gazali, El-Mustesfa min i'lmil-usul (Izbor iz nauke o metodologiji islamske jurisprudencije), (Darul-ulumulhadise, Bejrut, bez godine izdanja), i sa dodatkom u istom kompletuknjizi: Fevatihur-rehamut bišerh musellemis-subut (Osvajanja samilosti sa komentarom onoga što je a priori vjerodostojno), Muhibbullah b. Abduš-Šekur, (Darul-ulumil-hadise),

8. El-Hummam (En-Nizam) i grupa učenjaka iz Indije El-fetava elhindijje fi mezhebil-imamil-e'azami Ebi Hanifeten-Nu'man (Indijske decizije u pravnoj školi imamul-e'azama Ebu Hanife En-Nu'mana, poznate i kao El-fetava el'alemkirijje) (Daru ihjait-turasil-arebi, Bejrut, četvrto izdanje, bez godine izdanja), sa dodatkom još dvije knjige u istom kompletu-knjizi:

9. Fetava Kadija han (Decizije Kadija Hana), i

10. El-fetava el-bezazijje (Decizije Bezazija),

11. dr. Fikret Karčić, Šerijatski sudovi u Jugoslaviji 1918-1941, (Islamski teološki fakultet Sarajevo, Sarajevo, 1986.), 
12. Fikret Karčić i Enes Karić, Šrijatsko pravo u savremenim društvima, (Sarajevo, 1998.)

13. Građansko pravo, Opšta enciklopedija Larousse, (Vuk Karadžić, Beograd, 1971), I, 249.

14. H.M. Handžić, Kodificiranje šerijatskog prava kod raznih pravnih škola, predgovor u: Tumač šerijatskih propisa (H. Muradbegović)

15. Ibrahim b. Muha'mmed El-Halebi, Multekal-ebhur (Sastajalište mora), (Muessesetur-risale, 1989.),

16. Medželle i ahkjami šerije (Otomanski gragjanski zakon), (Tisak i naklada Daniela A. Kajona, Sarajevo, 1906. i reprint izdanje, nakon sto godina koje je priredio i dopunio Mehmedalija Huremović, Sarajevo, maj, 1997.).

17. Muhammed b. Ali Eš-Ševkani, Iršadul-fuhul ila tahkiki-lhakki min i'lmil-usul (Vodič znamenitima u postizanju istine u metodologiji islamske jurisprudencije), ,199 乏ilmijije,-kutubil-Darul)

18. Muhammed El-Emin Eš-Šenkiti, Muzekkiretu usulil-fikh (Skripta metodologije islamske jurisprudencije), (El-Mektebetus-selefijje, Medina, 1391.h.),

19. Muhammed Emin, poznat kao Emir Padišah, Tejsirut-tahrir, šerh Emir Badišah, ala Kitabit-tahriri fi usulil-fiqhil-dz̃ami’i bejne-stilahajjilhanefijjeti veš-šafíijjeti (Jednostavna, lahka redakcija, komentar Emira Padišaha na knjigu Spis o metodologiji islamske jurisprudencije s komparativnom metodom hanefijske i šafijske škole), (Darul-baz, bez godine izdanja),

20. Muhammed Emin, poznat kao Ibnu Abidin, Hašijetu reddil-muhtar, poznata kao Hašijjetu Ibni Abidin (Glosa Ibni Abidina), (Darul-fikr, 1979.),

21. Muhammed Et-Tahir, Usulul-fiqh (Metodologija islamske jurisprudencije), (Dar Bu Selame, Tunis),

22. Muhammed b. Idris Eš-Šafi'i, Er-Risale, bitahkik ve šerh Ahmed Muha'mmed Šakir (Poslanica, sa identifikacijom i komentarom Ahmeda Muha'mmeda Šakira), (El-mektebetul-ilmijje),

23. Muhammed b. Idris Eš-Šafi'i, El-Umm (Majka), kompendijum Muzenija, (Darul-ma'rife, Bejrut, Libanon), 
24. Muharem Štulanović, Uvod u šerijatsko pravo (fikh) i njegovu metodologiju (usuli fikh), (Bihać, 2002),

25. Mustafa Ahmed Ez-Zerka, El-Medhalul-fikhil-a’mm (Opći uvod u islamsko pravo), (Darul-fikr, 1968.),

26. Prof. dr. Mustafa Imamović, Historija države i prava Bosne i Hercegovine, (Sarajevo, 1999.),

27. Mustafa Ahmed Ez-Zerka, El-Medhalul-fikhil-a’mm (Opći uvod u islamsko pravo), (Darul-fikr, 1968.),

28. dr. Vehbe Ez-Zuhajli Usulul-fiqhil-islamijj (Metodologija islamske jurisprudencije), (Darul-fikr, 1986.),

29. dr. Vehbe Ez-Zuhajli, El-Fikhul-islamijju ve edilletuh (Islamsko pravo i njegovi dokazi), (Darul-fikr, Damask, 1984.),

30. Vojislav Spaić, Nasljednopravni običaji u BiH nakon Austro-Ugarske okupacije, Akademija nauka i umjetnosti BiH, knjiga XXXII., Odjeljenje društvenih nauka, knjiga 11., Sarajevo, 1967.

31. Zejnul-A'bidin b. Ibrahim b. Nudžejm, El-Ešbahu ven-nezairu ala mezhebi Ebi Hanifeten-nu'man (Sličnosti i uporednosti pravne škole Ebu Hanife En-Nu'mana), (Darul-kutubil-ilmijje, Bejrut, 1993.),

32. http://www.taddart.org/?p=12736

33. http://www.taddart.org/? $\mathrm{p}=12736$ 
Muharem Stulanovic, $\mathrm{PhD}^{13}$

\section{MAGALLA - A NEW PARADIGM FOR APPLICATION OF A MODIFIED, SHARIAH, SUBSTANTIVE LAW IN A JUDICIAL PROCESS}

\section{Abstract}

Substantive law is the law which is applied when the court decides on the merits of the case within the procedure, and formally it refers to the rules of procedure, for example a material Penal Code, a formal Code of a Criminal Procedure. Magalla, which will be discussed in this paper, contains a form of a codified, Shariah, substantive law.

Historical analysis of the development of Islamic legal thought indicates that the Islamic law-figh, has gone through several different phases or eras of development and systematization in the past. Notable is the division made by Mustafa Ahmad Az-Zarqa, who mentions seven different phases, acceptable for explanation of this phenomenon and modern codification of Islamic law. Seventh phase, which according to the author includes the development of fiqh from the appearance of Magalla until present day, is characterized by three important things. First of them is: accepting and declaring that "Magallah AlAhkam Al-Adliyye" is a general civil law taken from the Hanafi fiqh.

In its chapter Civil Law, General Encyclopedia Larousse mentions that the former country of Yugoslavia did not have a single civil legal territory in the period between the two world wars, the First and the Second, but consisted of six areas of the law. Bosnia and Herzegovina was a special area of civil law where "the laws of the Ottoman world (Magalla), Muslim religious law (Shariah), denominational Christian law, customary law and OAGZ as an additional right have been applied". This qualification about Shariah and Magalla is incorrect for the experts of Shariah and Islamic figh, but it reflects the attitude of conventional lawyers and their lack of knowledge and understanding of the essence of the Shariah law, because neither is Magalla a secular law, therefore atheistic, nor is Shariah a religious law only for Muslims.

${ }^{13}$ Islamic Pedagogical Faculty in Bihac. 
This can be even seen in the original name of Magalla which is stated in the title of its translation in the Bosnian language and reads: 'Magalla and Ahkam Al-Shariah'. This indicates that Magalla represents a commonly known codification of Shariah law or Hanafi law in the field of so called Al-Fiqh AlMua'melat.

The main characteristic of the legal proceedings of Islamic law lies in the large dispersion and disunity among legal views and opinions, which gave been given by the legal experts through legal reasoning which was legitimate regardless of everything, and given under the terms of the methodology of Islamic jurisprudence, through the so-called Fiqh Al-Tafsiri and Al-Tafsili (commentary and scientific explanation) derived by fundamental scientific methodology from the texts and sources of the Shariah as the largest and most comprehensive legal heritage the world has ever known, represented in the Islamic law schools (Madhhabs) of the famous scholars with separation of methodological and legal-practical nature which encountered problems in the process of application. It was a good enough reason to try the new form of codification which will be achieved by creating Magalla whose greatest quality was that it distinguished between a scientific, professional law which is explained, taught and interpreted, and the rights which represent a material, court source in the form of only one selected opinion converted to a article/paragraph. This is an epoch-making, revolutionary breakthrough in the application of Islamic fiqh and can rightly be considered as a new paradigm of application of a codified, Shariah, substantive law in judiciary process and a major step towards a uniformed, unified interpretation and application of law and uniformity of judicial practice.

The legal basis for all of this was confirmed and explained in the Paragraph 1801 of Magalla which reads that if the Sultan is to issue an order / instruction which is to be applied on certain issue because it is in favor of the people and because it is more appropriate for modern times, then is not within the competence of judges to rule and act upon on some other opinion and attitude which is opposite of this, and if the judge would do that, his verdict would not be final and enforceable. Confirmation of this can be found in the 16th article of Magalla which reads: "Ijtihad, the attitude of a legal expert is not abolished by the ijtihad, legal reasoning of the same type of another expert." 
Keywords: Magalla and Abkam Al-Shariyye (Ottoman civic law), Magallah Al-Ahkam Al-Adliyye (Code of legal rules), Fiqh, codification of Fiqh Ilaw, Ijtihad, Mujtahid Al-Mutlaq, legal reasoning, the traditional sources of law, uniformly homogeneous interpretation and application of law, unification of judicial law 
الأستاذ الدكتور محرم شتولانوفيتش عا

المجلة - النموذج الجديد لتطبيق الشريعة المقننة المادية في السلطة القضيائية

\section{الخلاصية}

القانون المادي هو ما تطبقه المحكمة عندما تبت في جوهر الأشياء داخل القضياة، وبشكل صوري تتناول شروط الإجراء، وعليه فإن القانون المادي هو قانون العقوبات،

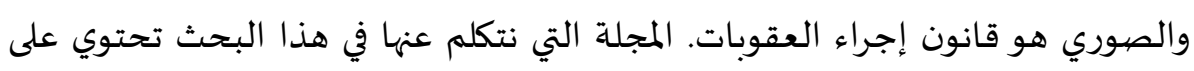
نوع من القانون المادي المقنن.

التحليل التاريخي لمراحل تطور الفكر الفقهي يدل على أن الفقه الإسلامي في تطوره وتنظيمها مر بأكثر من طور ومرحلة، ومن بين التقاسيم الكثيرة هناك تقسيم اعتمده مصطفى أحمد الزرقا حيث ذكر سبع مراحل تطور الفكر الفقهي المختلفة وهو تقسيم ومنيم

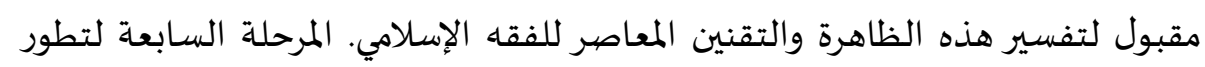

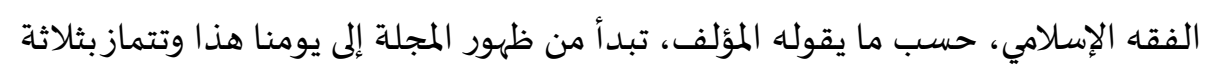

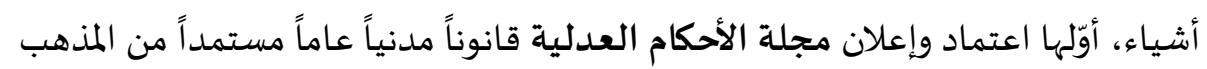
الحنفي.

تذكر موسوعة Larousse العامة في قسم القانون المدني أن يوغسلافيا السـابقة

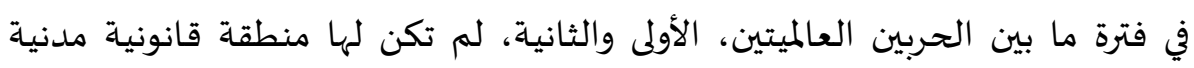

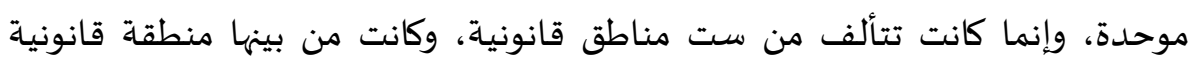

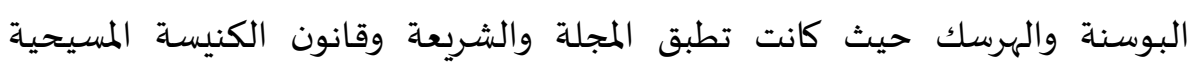

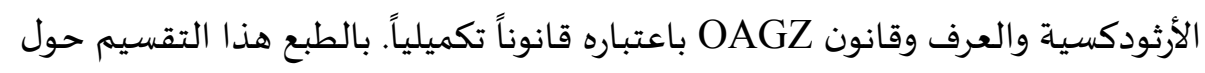

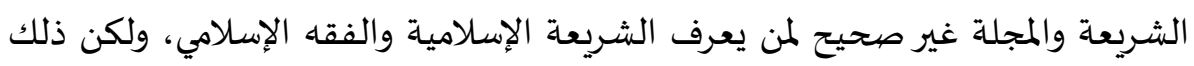

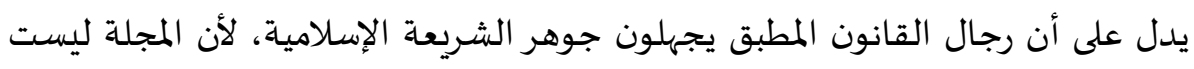

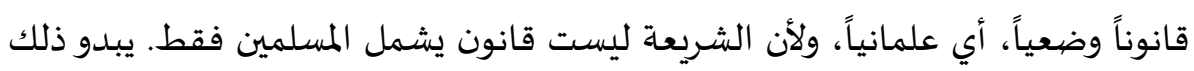

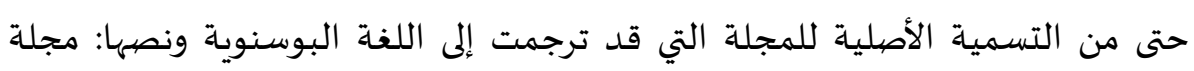


الأحكام الشرعية ويدل على أن المقصيود هو تقنين الفقه الإسلامي المعروف أو المذهب الحنفي في مجال المعاملات.

الميزة الرئيسية للمجلات الفقهية هي الاختلاف وعدم التوحد في المواقف والآراء

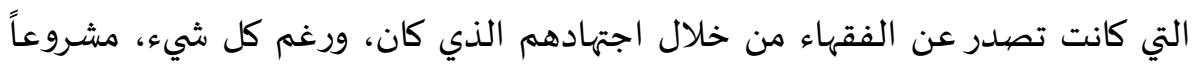

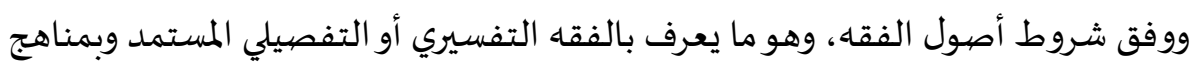
علمية من مصادر الشريعة باعتباره أضخم ثروة قانونية عرفها العالم والتي تمثلت في

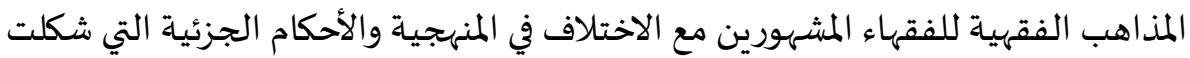

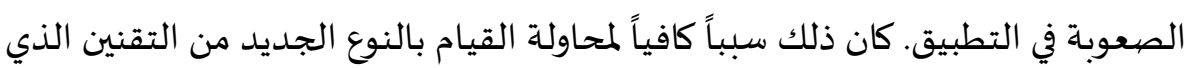

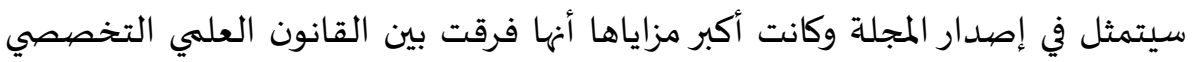

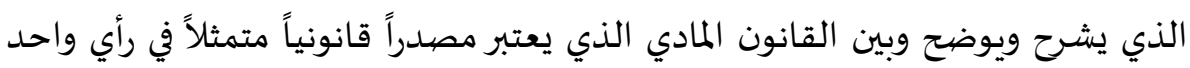

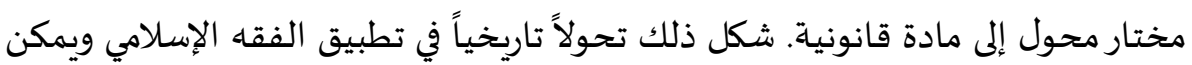

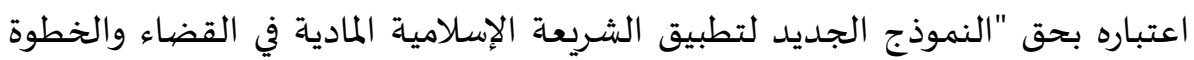
الكبيرة إلى التفسير الموحد وتطبيق القانون وتوحيد العمل القضيائي".

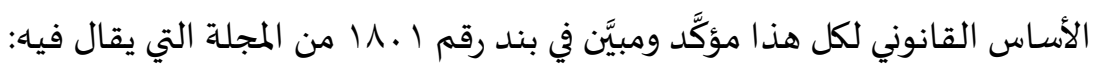

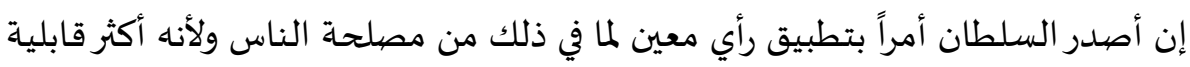
للتطبيق في العصر الحديث، فإنه ليس من حق القاضي أن يصيدر الأحكام ويعمل وفقاً

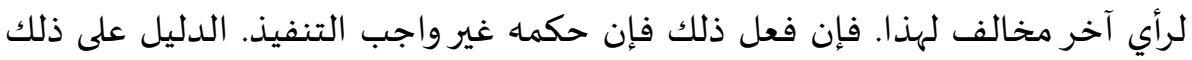
هو بند رقم 17 من المجلة الذي يقال فيه: لا ينقض الاجتهاد بمثله.

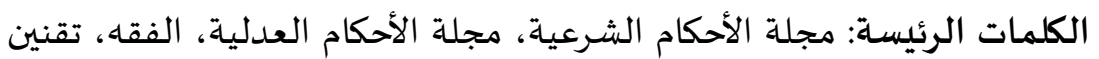

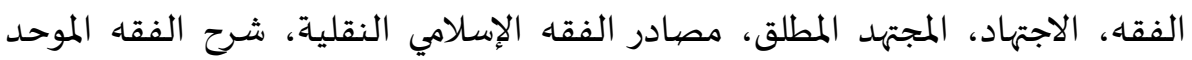
وتطبيقه، التطبيق القضائي الموحد 